\section{Ivan Mirnik}

Muzejski savjetnik u mirovini

Pregledni rad / Subject review

UDK / UDC: 737.2:069(497.5 Zagreb)

737.2 Marschall, R.

737.2 Kerdić, I.

9. 6. 2014.

\title{
Rudolf Marschall i Ivo Kerdić
}

Ključne riječi: medalje, plakete, Ivo Kerdić, Rudolf Marschall

Keywords: medals, plaquettes, Ivo Kerdić, Rudolf Marschall

Autor posvećuje pozornost životu i radu glasovitoga bečkog medaljera i kipara Rudolfa Marschalla, čiji je učenik bio i Ivo Kerdić. Dvije Marschallove plakete izrađene su za naše krajeve: ona iz 1901. u povodu otvaranja bosansko-hercegovačke željeznice prema Dubrovniku i ona iz 1905. u povodu Strossmayerove smrti.

Vjerujemo da je tko god posjetio nepregledne Vatikanske muzeje, lutajući ili idući ciljano kroz prostrane galerije i hodnike, prije ili poslije ispred jednog prozora naletio na neobični pilastar od lapis lazulija, pravo remek-djelo secesije, na vrhu kojeg je zlatna skulptura Dobrog Pastira sa svojim stadom. Bio je to poklon njegova apostolskog veličanstva Franje Josipa I. Njegovoj Svetosti papi Leonu XIII. u povodu papina zlatnoga svećeničkog jubileja. Autor toga careva poklona bio je Rudolf Ferdinand Marschall. Osim što je bio jedan od najbriljantnijih i najdugovječnijih austrijskih medaljera, poznat je u povijesti umjetnosti medalje po neugodnoj aferi Marschall.

Nešto o toj tzv. aferi Marschall opisao je očevidac, svjedok Ivo Kerdić, ${ }^{1}$ Marschallov hrvatski učenik, u svojim još neobjelodanjenim memoarima Moj život i uspomene. Te je uspomene tijekom Drugoga svjetskog rata i neposredno nakon njegova završetka I. Kerdić diktirao nekoj mladoj, nedovoljno obrazovanoj i neiskusnoj tipkačici, koja je mnoga imena zapisala krivo, a I. Kerdić rukopis nije više stigao korigirati. Jedan primjerak tih zapamćenja autor ovih redaka dobio je na poklon od kiparove mlađe kćeri Slavice, recte Vjekoslave Kerdić. Evo, doslovno citiramo što je o Rudolfu Marschallu Ivo Kerdić imao kazati:
»... Carski Beč je u teškoj brizi. Ni Cesar ne izlazi već proviruje iza zastora gledajući silu budućega svijeta.

Za vrijeme štrajka imao sam dosta vremena na raspolaganje te sam jednoga dana posjetio moga kolegu gravera Čejku, rodom Čeha a kojeg sam upoznao u češkom društvu `Komenski< koji je bio upisan u specijalnu školu za gravere i medaljere na Akademiji kod professora Talenhaima (sic! Tautenhayn), znamenitog profesora te vrsti. Po nagovoru Čejke prijavim se kod Prof. Talenhaima (sic! Tautenhayn), i isti mi prizna ispit kod Bitterlicha, ${ }^{2}$ stim da moram napraviti sve ispite za opči tečaj a sam mi pak obeča da će mi priznati izgubljeni semestar ako budem dobro napredovao. Tako sam bio primljen na Akademiji u specijalnu školu za gravere i medaljere.

No kako je nemoguće u životu imati nešto bez peripetija tako ni ovoga puta nije moglo proći glatko. Nešto pod konac semestra bude umirovljen prof. Totehnaim (sic! Tautenhayn) po volji Cesara Austrijskog i bez pristanka senata Akademije. Na njegovo mjestu bude imenovan profesor Marschal (sic! Marschall) bez izbora senata po dekretu Njeg. Vel. Cara Franja Josipa. Ovaj dekret onemogući prof. Marschala (sic!) uopće na Akademiji. Senat je osporio taj dekret. Nastanu veće i manje afere, djaci stupe 


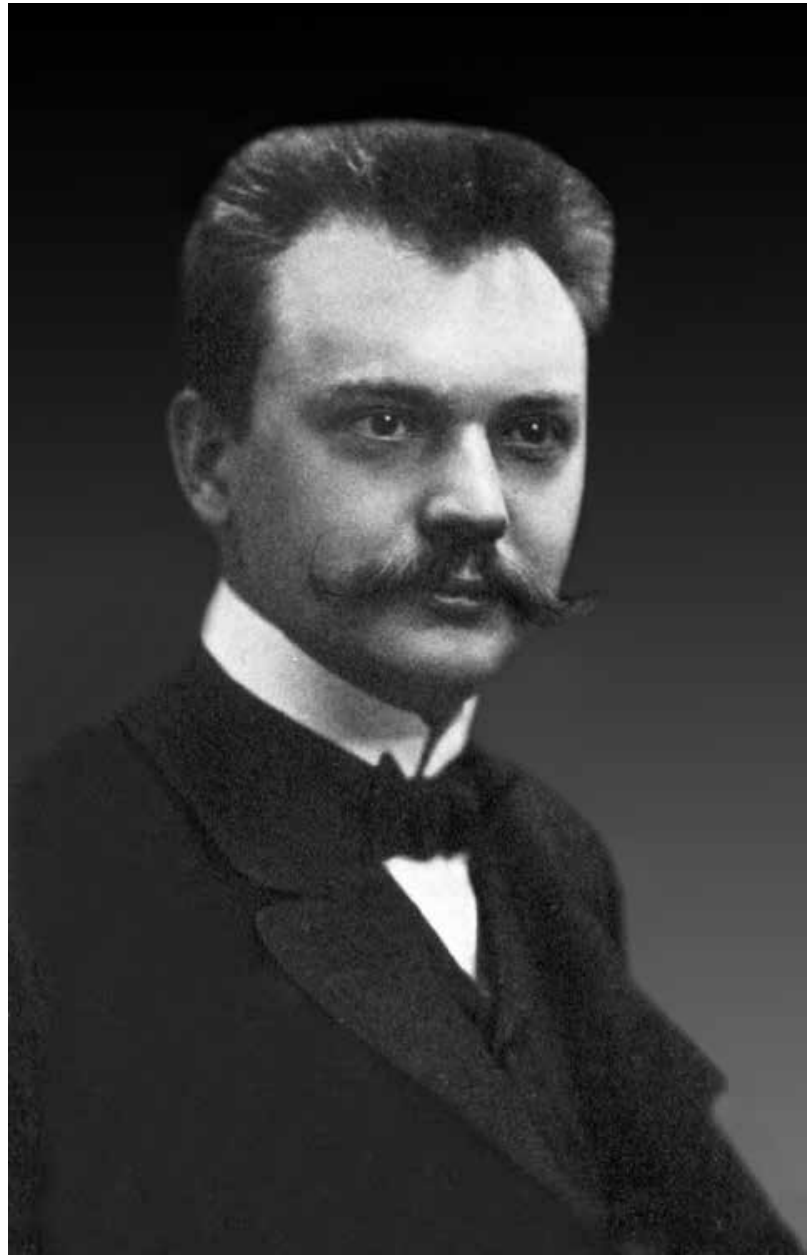

1. Rudolf Marschall, oko 1899. (izvor: AUGUST RITTER VON LOEHR, bilj. 17, t. XXIX) / Rudolf Marschall, ca. 1899 (source: AUGUST RITTER VON LOEHR, note 17, tab. XXIX)

u štrajk kao i profesori te škola bude zatvorena dulje vremena. Ministar prosvjete Hartl imao je tešku muku dok je tu njemu samome kao i Cesaru neugodnu aferu skinuo $s$ dnevnog reda. Cesarov dekret nije se mogao povući a Senat Akademije nije htio odstupiti od svoje autonomije t.j. u ovom slučaju da sami biraju profesore. Napokon ministar Hartl nadje rješenje i to osnuje specijalnu školu za gravere i medaljere ${ }^{3}$ te istu povjeri profesoru Marschalu (sic!) da ju vodi izvan akademije kao samostalno akademsko tijelo. To je rješenje bilo bolje nego dotadanje, jer na akademiji nije bilo za izdržati. Njemački studenti nisu nama upisanima dozvolili u klasu te zbog toga dolazilo i do afera na sablje pa sam i ja bez punomočstva morao braniti čast mog profesora Marschala (sic!).

Meni lično bilo je dosta te afere pak sam se uputio u Prag da bi pokušao naći sebi mjesto. U Pragu mi je obečao prof. Miselbeck (sic! Myslbek) ${ }^{4}$ mjesto no do toga nije došlo jer sam u međuvremenu dobio pismo od Čejke, u kojem mi javlja da se vratim i to po želji prof. Marschala (sic!), kao i da će mi priznati uvjete od prof. Totenhaima (sic!), t.

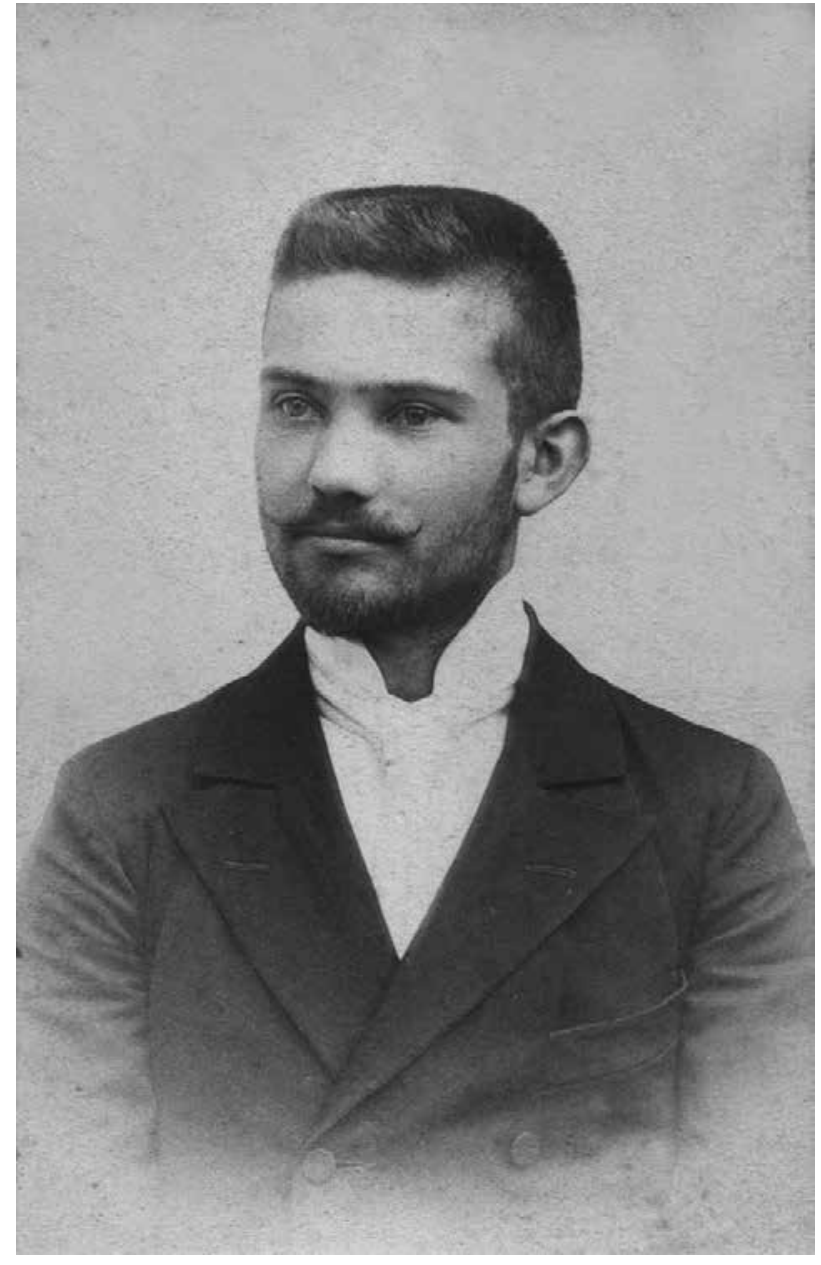

2. Ivo Kerdić, oko 1900. (foto: Arhiv I. Kerdića, Nadbiskupijski arhiv u Zagrebu) / Ivo Kerdić, ca. 1900 (photo: Ivo Kerdić's private archive, Zagreb Archdiocese Archives)

j. da ću odmah biti primljen u specijalnu školu. Tako sam se ponovno vratio u Beč. 1905-06 počele su moje studije a svršio sam specijalnu graversku i medaljersku školu 1911.

Kroz sve godine mojih studija ja sam napredovao $\mathrm{u}$ koliko je to bilo moguće uz moje teške prilike. Prije podne radio sam na akademiji, popodne $u$ radioni a na večer sam se pripravljao za ispite koje sam morao napraviti te godine na akademiji da budem upisan kao redoviti student $\mathrm{u}$ specijalnu školu. Za taj ispit trebao sam se pripremiti iz historije umjetnosti, poče historije, anatomije, štihiesa (?), perspektive, inteligencbrifunga i t. d. ali kako moje znanje iz njemačkog jezika bilo zadovoljavajuče to sam muku mučio dok sam sve to tu godinu savladao. Sve ispite sam prošao čak neke i sa pohvalom. Te ispite sam polagao pred komisijom na akademiji lijepih umjetnosti. Možete misliti moj položaj kao studenta prof. Marschala (sic!), a još k tomu Hrvata koji je za tu Njemačku gospodu bio trn u oku. Uza sve te peripetije dobro sam se držao i kao što rekoh dobro prošao pa čak po neki put prošao i pohvalno. Za to vrijeme mojih studija živio sam od zaslužbe što sam jednom pogrebnom 


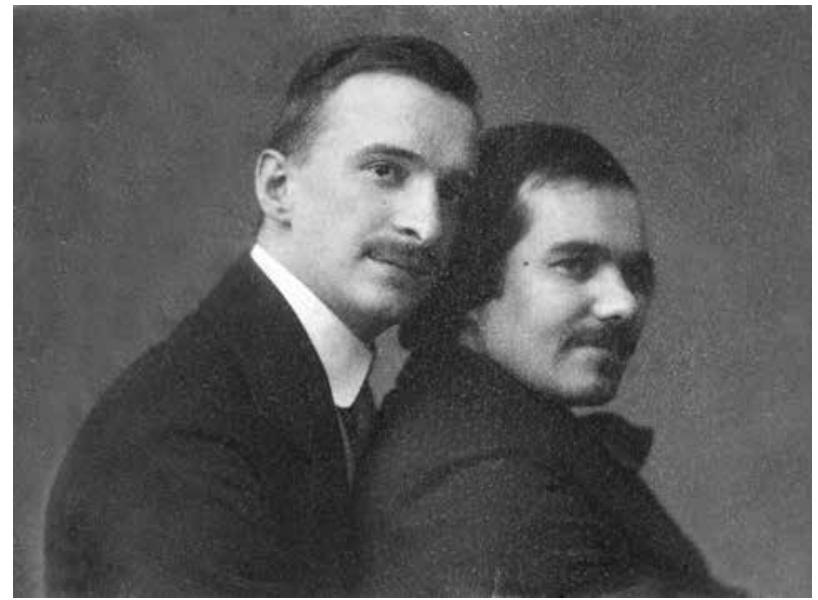

3. Ivo Kerdić i rođak Miško, Beč, 1910. (foto: Arhiv I. Kerdića, Nadbiskupijski arhiv u Zagrebu) / Ivo Kerdić and his cousin Miško, Vienna, 1910 (photo: Ivo Kerdić's private archive, Zagreb Archdiocese Archives)

poduzeću (društvu) snimao posmrtne maske. Ta je profesija u ono doba neko vrijeme u Beču bila vrlo unosna.... «"

Vrijedno je spomenuti da je 1910. I. Kerdić kao student četvrte godine primio školsku nagradu Ministarstva za bogoštovlje i nastavu za kompoziciju (tema bijaše majčinska ljubav). ${ }^{6} \mathrm{U}$ nastavku svojih memoara Kerdić se ponovno osvrće na svoga profesora:

"... Moj profesor Rudolf Marschal (sic!) Koimör - medaljer, (tako je bilo pisano na vratima njegovog ateljea) izgleda da je $\mathrm{e}^{7}$ francuskog porijekla a po njegovom izražavanju u medaljerstvu opaža se crta profinjenog romanskog ukusa. Njegovi radovi nisu obojeni tvrdoćom njemca već ličnošću tradicije i osebujnosti. On sam se priznaje njemcem u njegovoj osobi nema ništa što bi Vas na moment moglo uvjeriti da je to znameniti medaljer Rudolf Marschal (sic!) čije ime bijaše najpopularnije od sviju umjetnika toga doba. Uveden u krugove dvora milosnik Njegova Veličanstva Franje Josipa kojega potretira za novac. Sve to njemu donjelo više afera i neugodnosti u životu počevši od Akademije ljepih umjetnosti do svakog jalnuša, njegovog kolege. Njegovo ime je dan na danom na računu. Nakon prvog svjetskog rata prof. Lehr (sic! Loehr), direktor numizmatičke zbirke u Beču ocjenio je prof. Marschala (sic!), ne mareći za svoje dobro ime odnosno posljedice koje će proizaći za njega iz te ocjene. Dr. Lohr (sic!) bio je pravedan u svojoj ocjeni no Marschal (sic!) nije podnosio pravedne ocjene jer je neprijateljstvo između Lohra (sic!) i Marschala (sic!) raslo sve više otkada je Dr. Lohr (sic!) u numizmatičkom društvu iznjeo o mojoj medaljerskoj umjetnosti tada mi je moj profesor i meni ljubav otkazao. Njegovo držanje prema meni bilo je hladno od tog vremena. Moram priznati da me je mnogo cijenio i volio. Isto tako se je nepravedno ponašao prema kolegi Kaissu (sic! Käss) njegovom najboljem učeniku. Kao profesor bio je temeljit, od nas je tražio sve što se u školi

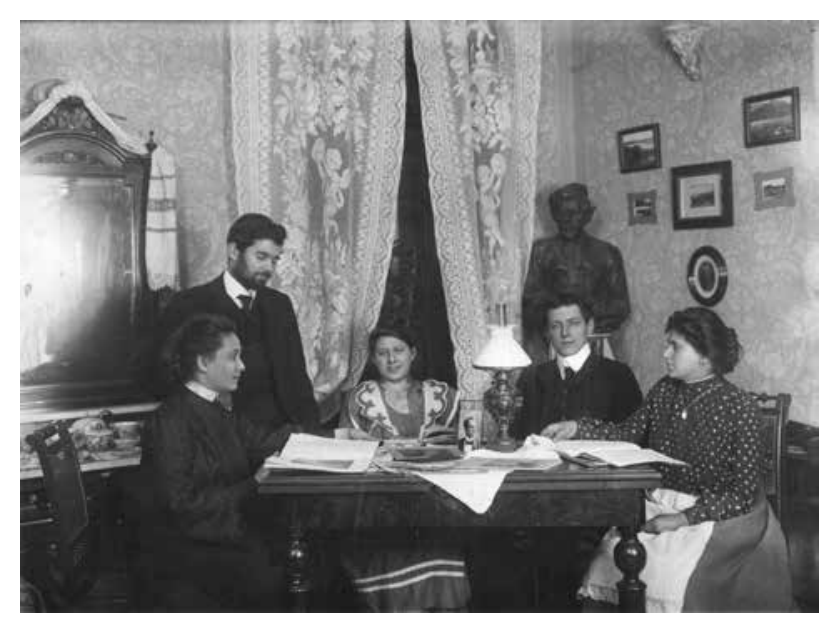

4. Ivo Kerdić i Mišo Milošević u krugu obitelji Bauer, Beč, oko 1910. (foto: Arhiv I. Kerdića, Nadbiskupijski arhiv u Zagrebu) / Ivo Kerdić and Mišo Milošević together with the Bauer family, Vienna, ca. 1910 (photo: Ivo Kerdić's private archive, Zagreb Archdiocese Archives)

dade naučit. Njegove korekture bile su pune razumjevanja ali ih je bilo previše malo, jer je prof. Marschal (sic!) bio toliko zaposlen sa okrunjenim glavama, Papom i višom aristokracijom te bogatašima, da je teško našao vremena da se sa nama pozabavi. Kao što sam rekao kada bi se sa nama pozabavio dao bi se u cijelosti.

Njegov umjetnički rad istakao se u portretima; tako na pr. portret glumca Savinskog (sic! Lewinski) na Burgtheatru. Ovim portretom uspinje se Marschal (sic!) na svojoj skali sve do Pape Leona XIII, Salamajera i drugih medalja. Kompozicija je njegova slaba strana pa je i bilo i afera u tom smislu. Cjeli njegov opus osjeća se u dubljoj osječajnosti. Njegovi portreti su slični i vjerni da u njima daje i zadnju boru na licu..."

U nastavku I. Kerdić govori o jednom vrlo darovitom kolegi, također Marschallovu učeniku, Josefu Kässu, ${ }^{8}$ koji je umro mlad, duševno poremećen, tijekom Velikog rata. Isto se tako sjeća već prethodno spomenutoga češkog umjetnika Jana Čejke (Czejka; Beč, 1878. - Kremnica, 1926.), ${ }^{9}$ koji je također prerano umro. Kad je nastala nova češka država, Čejku su zamolili da dođe u kremničku kovnicu, gdje je postao prvim graverom.

Jednom je prigodom R. Marschall I. Kerdiću posudio i nešto novca kako bi ga izvukao iz neke neugodne situacije, o kojoj su čak pisale i bečke novine. U nastavku I. Kerdić piše sljedeće:

"... Pod konac 1912 posjetio je prof. Frangeš ${ }^{10}$ mog profesora Marschala (sic!), da me konačno nagovore da primim mjesto na školi za Umjetni obrt u Zagrebu, te je bilo odlučeno da ću ja biti imenovan za prof na školi za umjetni obrt Malu plastiku i medaljerstvo uključivši vodjenje ljevaonice što je bilo zapravo uzrok da je on forsirao moje imenovanje i zahtjevao da još prije mog nastupa svršim gus ljevanje kod tvrtke Frömel koja je dugo vremena za njega 

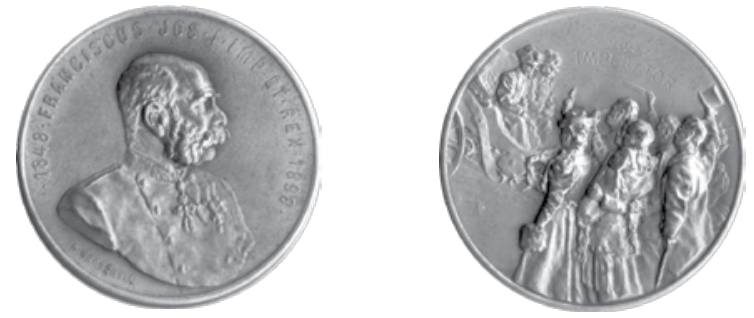

5. Rudolf Marschall, Franjo Josip I., 50. obljetnica vladanja 1898.; medaljica, srebro, veličina: $30 \mathrm{~mm}$, Arheološki muzej u Zagrebu / Rudolf Marschall, Franz Joseph I, 50 th anniversary of reign, 1898; medal, silver, dim.: 30 mm, The Zagreb Archaeological Museum

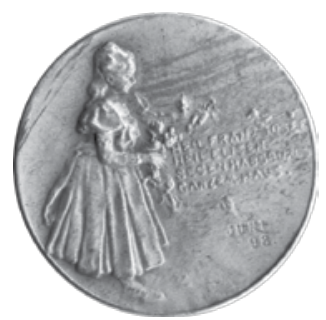

6. Rudolf Marschall, Franjo Josip I., 50. obljetnica vladanja 1898.; medaljica s dječjom povorkom, srebro, veličina: $30 \mathrm{~mm}$, Arheološki muzej u Zagrebu / Rudolf Marschall, Franz Joseph I, $50^{\text {th }}$ anniversary of reign, 1898, medal with children's parade, silver, dim.: 30 mm, The Zagreb Archaeological Museum
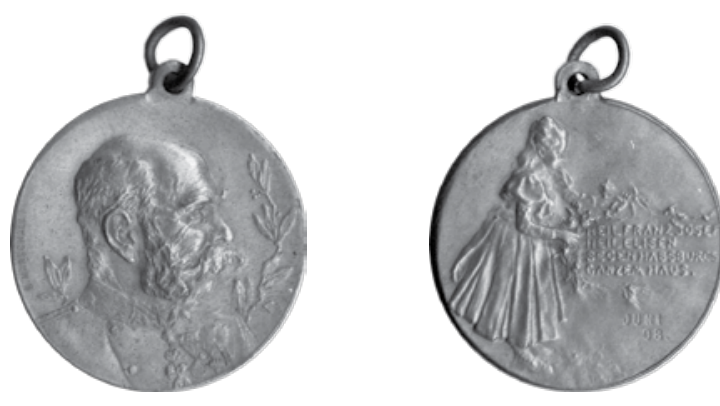

7. Rudolf Marschall, Franjo Josip I., 50. obljetnica vladanja 1898.; medaljica s dječjom povorkom, bronca, veličina: $30 \mathrm{~mm}$, Arheološki muzej u Zagrebu / Rudolf Marschall, Franz Joseph I, $50^{\text {th }}$ anniversary of reign, 1898, medal with children's parade, bronze, dim.: 30 mm, The Zagreb Archaeological Museum

ljevala, što sam ja i učinio, stekao iskustvo koje je meni bilo potrebno za vodjenje ljevaone uz moje već prije stečeno znanje u cizeliranju.... ${ }^{11}$

Rudolf Ferdinand Marschall (Beč, 3. XII. 1873. - 24. VII. 1967. $)^{12}$ pripadao je prilično velikoj skupini glasovitih medaljera austrijske secesije ili jugendstila. Ime njegova oca bilo je Matthäus (†1916.), a bio je vlasnik I. Österreichische Graveur- und Guillochieranstalt. Marschall zapravo nije rijetko prezime u Beču. Ime Rudolfove majke bilo je Hermine, rođ. Kittler. Zanimljivo je da je 1898. R. Maschall oženio jednu drugu Herminu, rođ. Lahner (17. XII. 1877. - 14. X.

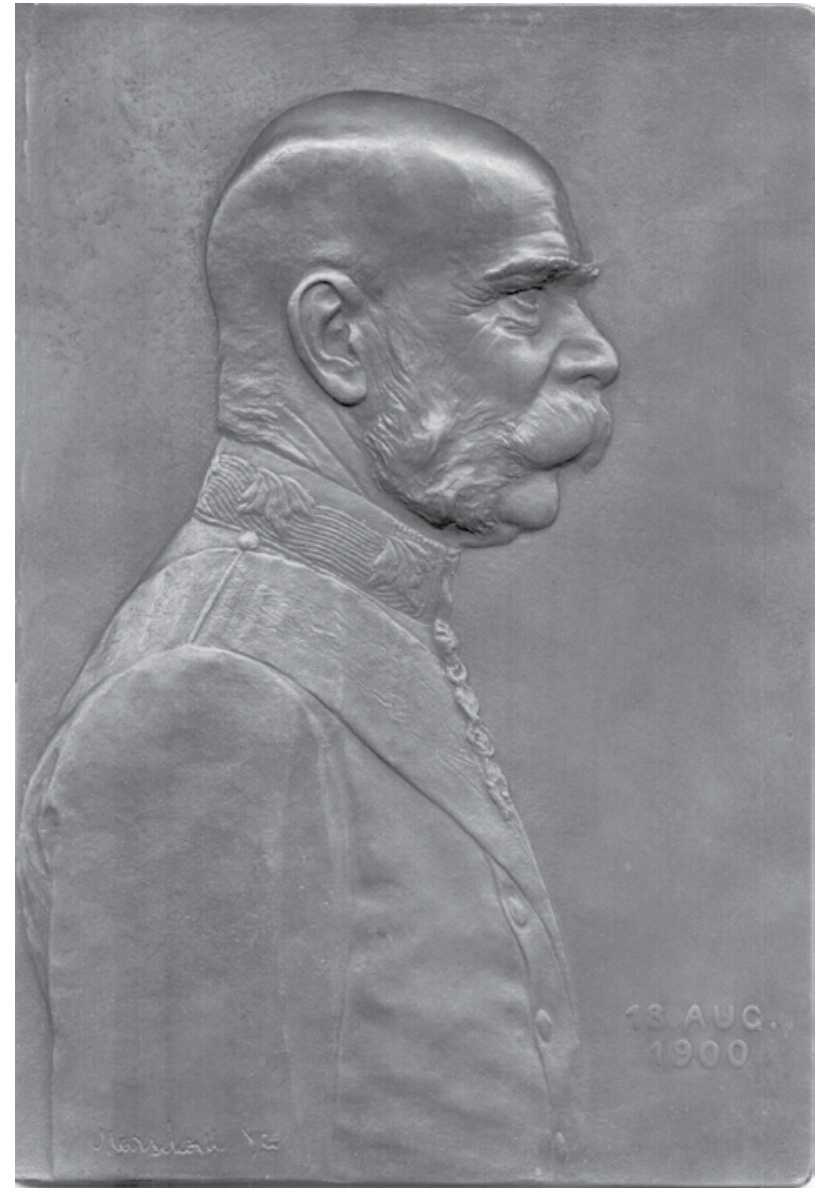

8. Rudolf Marschall, Franjo Josip I., 70. rođendan, 1900.; bronca, veličina: $158 \times 216 \mathrm{~mm}$, Arheološki muzej u Zagrebu / Rudolf Marschall, Franz Joseph I, 70 th birthday, 1900, bronze, dim.: $158 \times 216$ $\mathrm{mm}$, The Zagreb Archaeological Museum

1955.); dana 20. studenoga 1948. svečano su proslavili svoj zlatni pir, a prigodom proslave svetu misu služio je bečki kardinal-nadbiskup Theodor Innitzer. ${ }^{13}$

Učitelji R. Marschalla na bečkoj rezbarskoj (graverskoj) stručnoj školi (Fachschule der Graveure) bili su S. Schwarz, Schulmeister i Zapf. Već je kao vrlo mlad, 1891., primio svoju prvu srebrnu nagradnu medalju Donjoaustrijske komore za trgovinu i obrt (Niederösterreichische Handels- und Gewerbekammer) za neke svoje radove (crtě̌e, modele, grafike), a isto tako ga je nagradila i Udruga gravera (Genossenschaft der Graveure) srebrnom i brončanom medaljom. R. Marschall završio je studij 1898. Kao mnogi drugi mladi umjetnici koji su si to mogli priuštiti, proputovao je diljem Europe i posjetio Njemačku, Italiju i Francusku, kako bi se upoznao s tamošnjim umjetničkim životom. Potom se 1901. vratio kući i postao učenikom sjajnog umjetnika medalje Josepha Tautenhayna st., kojega je poslije i naslijedio na Akademiji likovnih umjetnosti (Akademie der bildenden Künste). Sljedeće tri godine proveo je modelirajući medalje, ali i sitnu i veliku skulpturu, privlačeći pozornost pozna- 

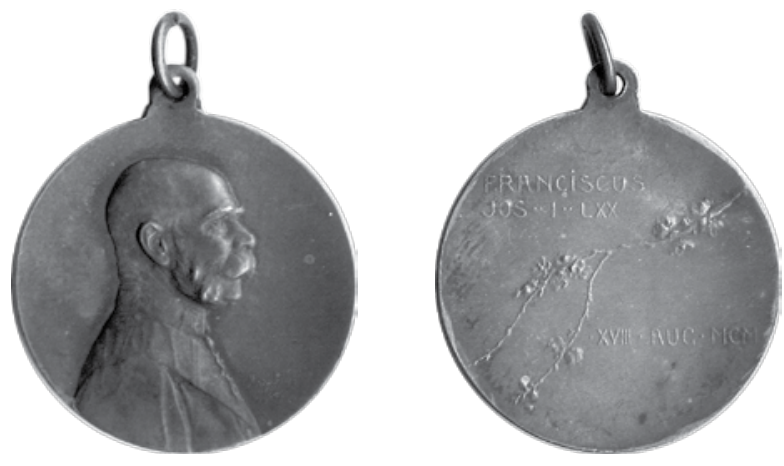

9. Rudolf Marschall, Franjo Josip I., 70. rođendan, 1900.; srebro, veličina: $30 \mathrm{~mm}$, Arheološki muzej u Zagrebu / Rudolf Marschall, Franz Joseph I, 70 ${ }^{\text {th }}$ birthday, 1900, silver, dim.: $30 \mathrm{~mm}$, The Zagreb Archaeological Museum
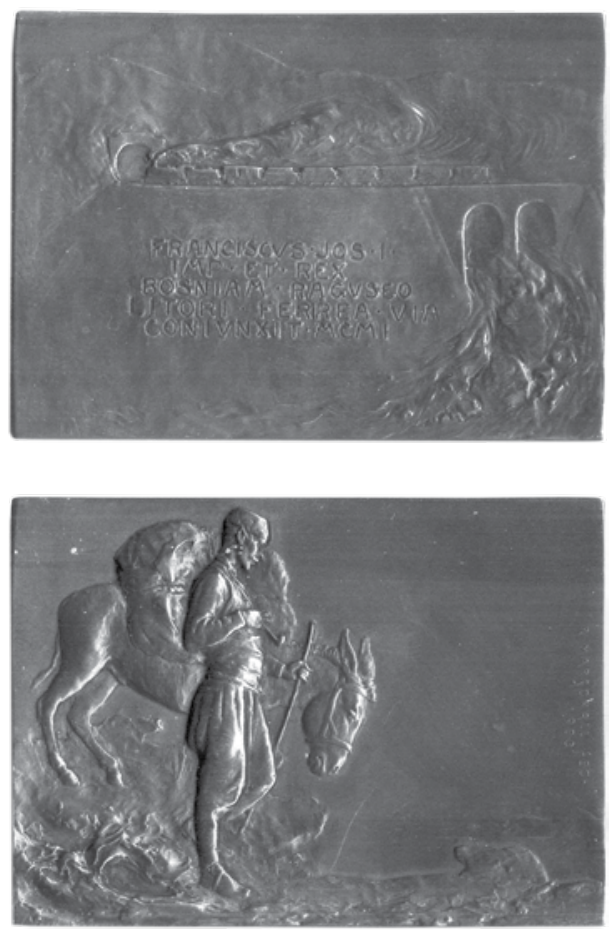

10. Rudolf Marschall, otvorenje bosansko-hercegovačkedubrovačke željeznice, 1901.; dvostrana plaketa, bronca, veličina: $61 \times 44 \mathrm{~mm}$, Arheološki muzej u Zagrebu / Rudolf Marschall, the inauguration of the Bosnian-Herzegovinian-Dubrovnik Railway, 1901, two-sided plaquette, bronze, dim.: $61 \times 44 \mathrm{~mm}$, The Zagreb Archaeological Museum

valaca i stičući nove nagrade. Jedna od tih bila je Fügerova zlatna medalja, a druga Gundelova nagrada za specijalne škole za portrete i opće studije. ${ }^{14}$ Godine 1902. na izložbi Društva umjetnosti odlikovan je državnom zlatnom medaljom za izložene svoje medalje. ${ }^{15}$

August (Oktavian Ritter) von Loehr, kustos i ravnatelj Numizmatičkog kabineta bečkoga Povijesnoumjetničkog muzeja, u prvome svesku svoje monografije o bečkim medaljerima opisuje trinaest Marschallovih radova, nastalih

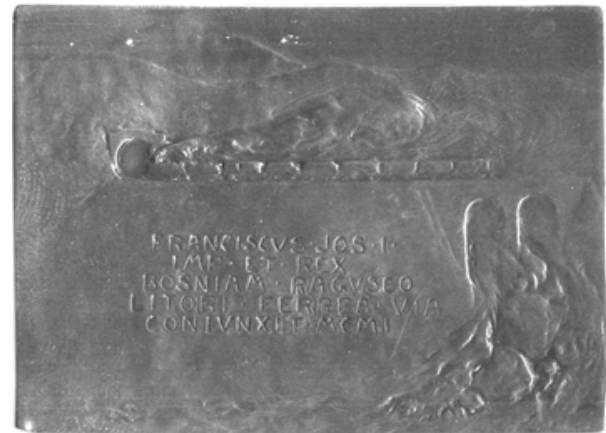

11. Rudolf Marschall, otvorenje bosansko-hercegovačkedubrovačke željeznice, 1901.; jednostrana plaketa, bronca, veličina: $61 \times 44 \mathrm{~mm}$, Arheološki muzej u Zagrebu / Rudolf Marschall, the inauguration of the Bosnian-Herzegovinian-Dubrovnik railway, 1901, uniface plaquette, bronze, dim.: $61 \times 44 \mathrm{~mm}$, The Zagreb Archaeological Museum
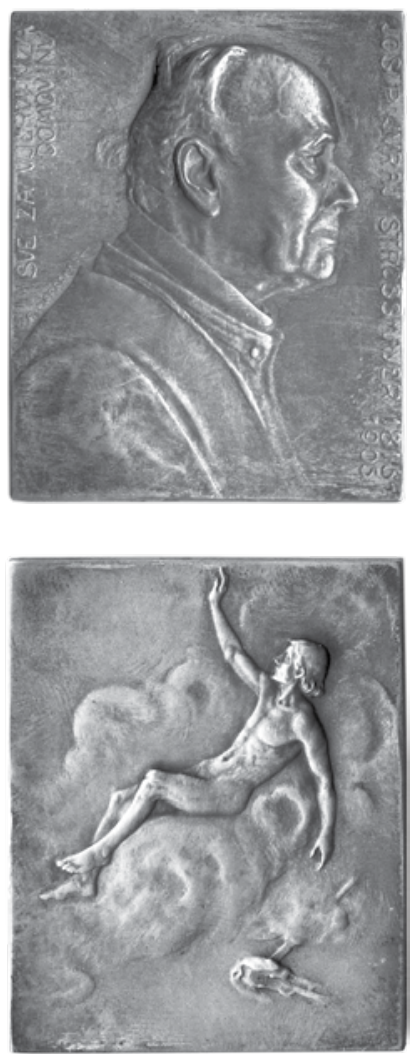

12. Rudolf Marschall, Josip Juraj Strossmayer, smrt 1905.; srebro, veličina: $41 \times 51 \mathrm{~mm}$, Arheološki muzej u Zagrebu / Rudolf Marschall, Josip Juraj Strossmayer, death, 1905, silver, dim.: $41 \times$ $51 \mathrm{~mm}$, The Zagreb Archaeological Museum

između 1894. i 1898. Među tim medaljama najdraža mu je ona s portretom glumca (Burgschauspieler) Josefa Lewinskog, no isto mu se svidjela i medalja nastala prigodom pola stoljeća careve vladavine, uz napomenu da je pomalo skicozna. Zanimljive su među Marschallovim radovima $\mathrm{i}$ »šarene« medalje, kakve su se dijelile na balovima, tzv. 

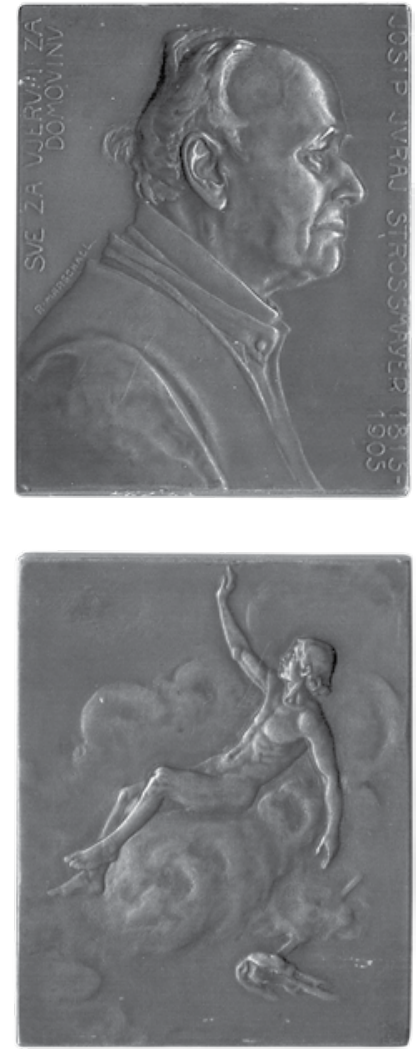

13. Rudolf Marschall, Josip Juraj Strossmayer, smrt 1905.; bronca veličina: $40 \times 51 \mathrm{~mm}$, Arheološki muzej u Zagrebu / Rudolf Marschall, Josip Juraj Strossmayer, death, 1905, bronze, dim.: $41 \times 51$ mm, The Zagreb Archaeological Museum

Damenspenden (Cotillons, kotiljoni), od kojih su reproducirane dvije, nažalost u crno-bijeloj tehnici. ${ }^{16}$ Marschall ih je izrađivao u tehnici polirane i nepolirane površine, a bile su ovješene na šarene vrpce. ${ }^{17}$

U nastavku, dodatnome svesku svoje monografije (1902.), Loehr je spomenuo medalje koje je Marschall izradio nakon velikih medaljerskih izložaba održanih 1900., u Beču (Prva medunarodna izložba suvremene medalje u Carskom i kraljevskome muzeju za umjetnost i obrt), kao i Svjetske izložbe u Parizu. Napisao je da se tako R. Marschall uvrstio među prvorazredne majstore male skulpture i hvalio ga uvelike zbog njegovih medalja nastalih od 1893. do 1901. godine. ${ }^{18}$ Leonard Forrer je pak popisao njemu poznatih četrdesetak medalja, nastalih između 1893. i 1906., izvedenih u različitim tehnikama (lijevane, kovane) i veličinama. ${ }^{19}$ Numizmatički časopisi stalno su pratili Marschallov umjetnički rad. ${ }^{20}$

Na Svjetskoj izložbi u Parizu 1900. R. Marschall je primio brončanu medalju, a za njegovu medalju s portretom istaknutoga austrijskog numizmatičara dr. Friedricha Kennera pisalo se da je un pûr chef doeuvre. ${ }^{21}$ Iste godine, 1900., hvalili su ga uvelike u nekom numizmatičkom časopisu: "Dem Schöpfer solch idealer Bilder müssen die Musen ihren Weihekuss auf die Stirn gedruckt haben. Allein das
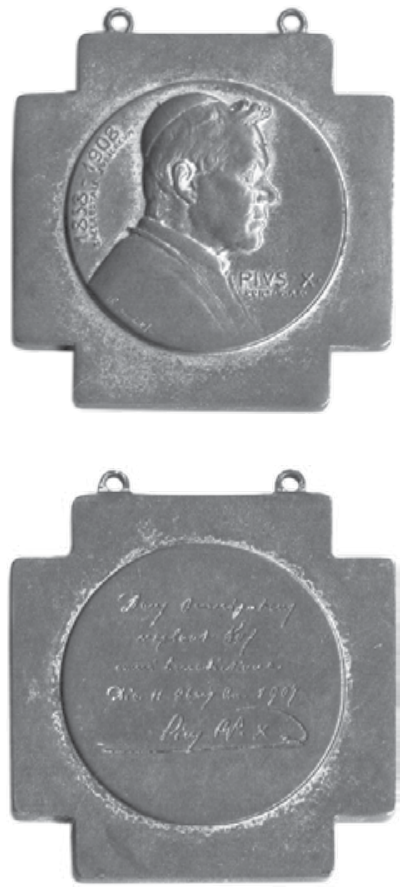

14. Rudolf Marschall, Pio X., zlatni svećenički jubilej 1908.; pozlaćena bronca, veličina: $40 \times 51 \mathrm{~mm}$, Arheološki muzej u Zagrebu / Rudolf Marschall, Pius X, golden jubilee of ordination to the priesthood, 1908, bronze gilt, dim.: $40 \times 51 \mathrm{~mm}$, The Zagreb Archaeological Museum

Verdienst des also Bevorzugten liegt in seinem Fleisse, seinem Talente erst Wert verleiht, denn nur durch diese war es möglich, dass Marschall in so jungen Jahren schon so Bedeutendes geleistet und so viele Erfolge aufzuweisen hat, welche leicht zur Selbstüberhebung, die gleichbedeutend mit Stillstand und Rückgang im Schaffen eines Künstlers ist, führen könnten. Bei Marschall ist dies nicht zu fürchten, denn er gehört zu jenen Künstlern, die stets an ihren eigenen Arbeiten strengste Kritik üben, die sich nie oder selten mit ihren Leistungen zufrieden geben und an ihrer künstlerischen Vervollkommnung unermüdlich weiter arbeiten. Auf seinen Reisen durch Deutschland, Frankreich und Italien hat er mannigfache Gelegenheit zu interessanten Studien gefunden, der stete Vergleich mit den besten Werken alter und neuer Meister hat ihm einen Maasstab fuer seine eigene Schöpfungen gegeben und ihm den weiten Weg vorgezeichnet, den er auf seiner künstlerischen Laufbahn noch zurückzulegen hat.. ${ }^{22}$

I nadalje je izlagao mnogo i često. Na primjer, 1906. je na jednoj izložbi bilo pokazano 19 njegovih medalja, u 26 primjeraka u Carskom i kraljevskom austrijskom muzeju za umjetnost i industriju (K. k. Oesterreichisches Museum für Kunst und Industrie). ${ }^{23}$ Godine 1908. sve su njegove medalje s carevim portretom pokazane na jubilarnoj izložbi koju je priredilo Austrijsko medaljersko i numizmatičko društvo. ${ }^{24}$ Tu je izložbu otvorio nadvojvoda Rainer, a posjetio ju je i sam 

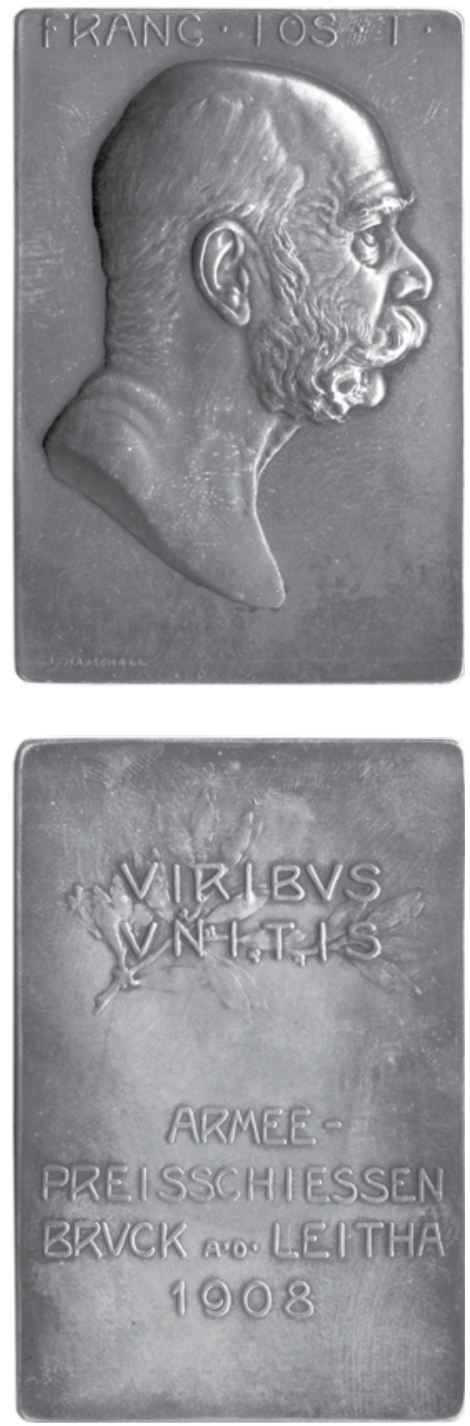

15. Rudolf Marschall, Franjo Josip I., 60. obljetnica vladanja 1908., Bruck an der Leitha, vojno natjecanje u pucanju; srebro, veličina: $46 \times 70 \mathrm{~mm}$, Arheološki muzej u Zagrebu / Rudolf Marschall, Franz Joseph I, $60^{\text {th }}$ anniversary of reign, 1908, Bruck an der Leitha, military shooting contest, silver, dim.: $46 \times 70 \mathrm{~mm}$, The Zagreb Archaeological Museum

car. Godine 1910. R. Marschall je sa 41 medaljom sudjelovao na izložbi suvremene medalje pri Američkom numizmatičkom društvu u New Yorku. Među tim medaljama bila je i jedna s likom sir Francisa Drakea, nastala 1907. Usprkos svemu tomu, nije se često pridruživao svojim kolegama na izložbama u Künstlerhausu. Nakon dugog vremena izlagao je ponovno 1943. u okviru proljetne izložbe Društva likovnih umjetnosti u Künstlerhausu. ${ }^{25}$ Kad je umjetnik dostigao svoj osamdeseti rođendan, otvorena je izložba 60 njegovih najboljih radova u Numizmatičkom kabinetu Povijesnoumjetničkog muzeja u Beču. ${ }^{26}$

Među tisuću medalja, koliko se smatra da je izradio, nalaze se portreti velikog broja poznatih i nepoznatih ličnosti,
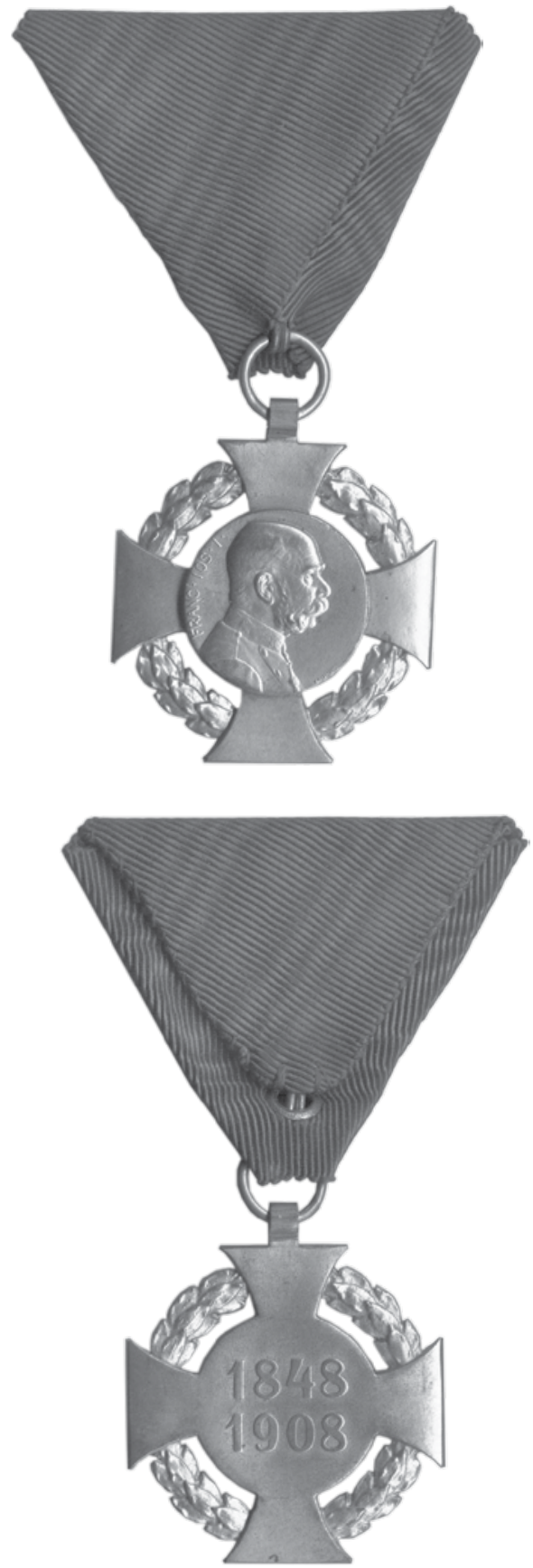

16. Rudolf Marschall, Franjo Josip I., 60. obljetnica vladanja 1908., jubilarni spomen-križ za činovnike; pozlaćena bronca, veličina: 37 mm, Arheološki muzej u Zagrebu / Rudolf Marschall, Franz Joseph I, $60^{\text {th }}$ anniversary of reign, 1908, The Jubilee Memorial Cross for Civil Servants, bronze gilt, dim.: 37 mm, The Zagreb Archaeological Museum

među koje se ubrajaju npr. Marie von Ebner-Eschenbach, ${ }^{27}$ spisateljica, Friedrich Kenner, ${ }^{28}$ numizmatičar, Paul Heyse, pisac, Karl Lueger, bečki gradonačelnik, austrijski predsjednik Wilhelm Miklas te kancelari Engelbert Dollfuss ${ }^{29} \mathrm{i}$ Leopold Figl, ${ }^{30}$ kao i mnogi drugi. R. Marschall je dobivao i zadatke da modelira i brojne nagradne medalje, tako 

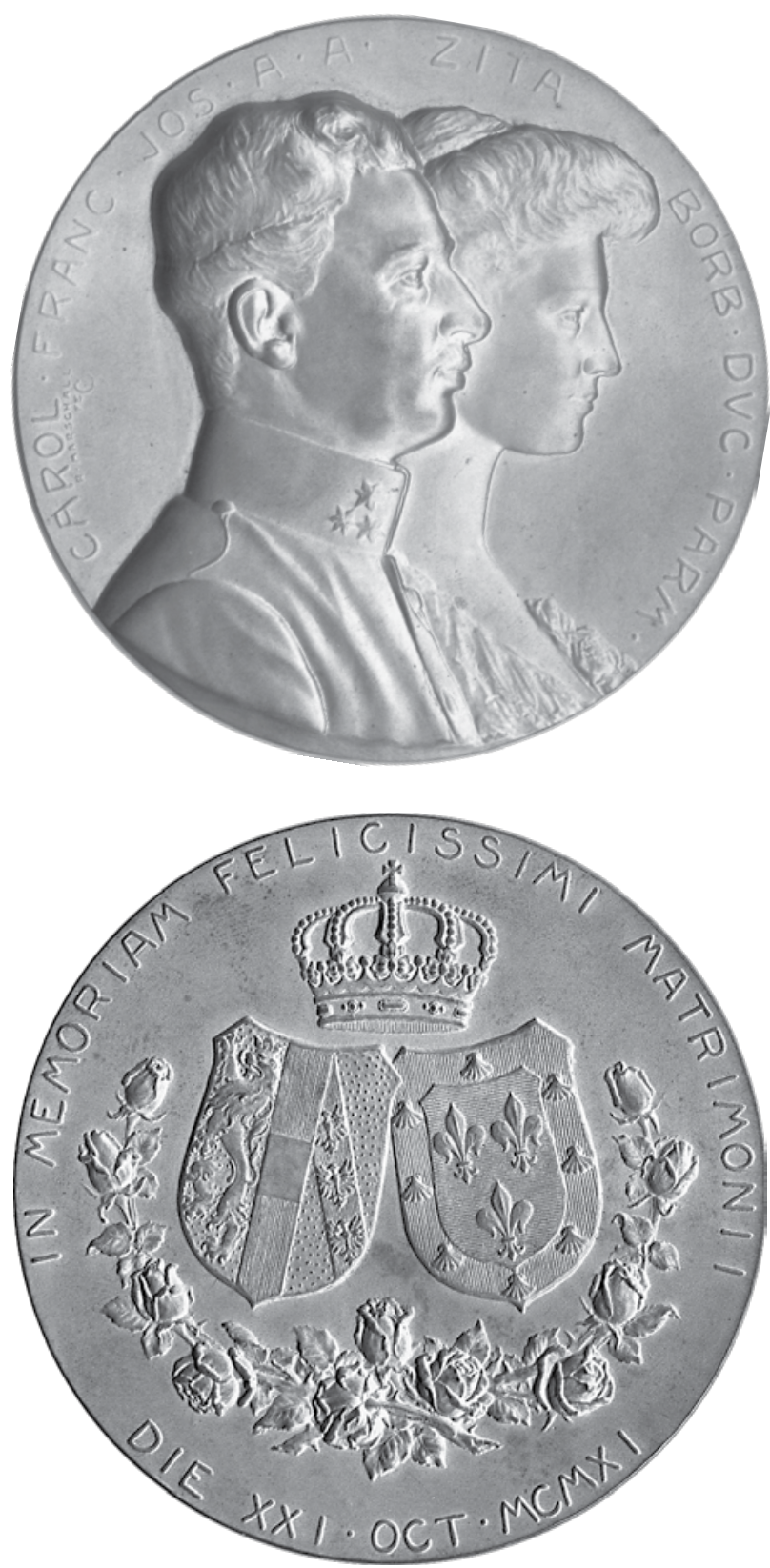

17. Rudolf Marschall, vjenčanje nadvojvode Karla i princeze Zite od Bourbon-Parme 1911.; pozlaćena bronca, veličina: $80 \mathrm{~mm}$, Arheološki muzej u Zagrebu / Rudolf Marschall, the wedding of archduke Charles and Princess Zita of Bourbon-Parma, 1911, bronze gilt, dim.: $80 \mathrm{~mm}$, The Zagreb Archaeological Museum

npr. državnu nagradu za Međunarodnu izložbu alkoholnih pića (Internationale Ausstellung für Spiritusverwertung und Gährungsgewerbe) 1903. godine. ${ }^{31}$

Već je u svojim mladim godinama stekao mnoga i visoka priznanja. Tako ga je papa Leon XIII. 1903. odlikovao komturskim križem Reda sv. Silvestra, ${ }^{32}$ dok je papa Pio X. pridodao zvijezdu toga istoga reda 1910 . godine. ${ }^{33}$ To odličje u zlatu umjetniku je u njegovu bečkom ateljeu uručio apostolski nuncij nadbiskup Granito di Belmonte-Gennaro. ${ }^{34}$ Godine 1903. imenovao ga je car Franjo Josip I. carskim i

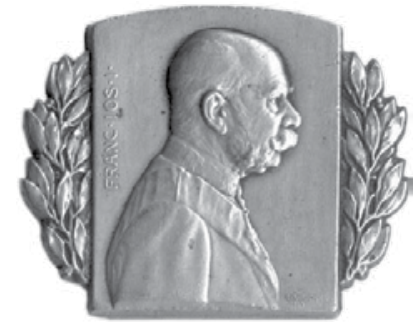

18. Rudolf Marschall, Franjo Josip I., ratna značka 1915.; kositar, veličina: $40 \times 33 \mathrm{~mm}$, Arheološki muzej u Zagrebu / Rudolf Marschall, Franz Joseph I, war badge, 1915, pewter, dim.: $40 \times 33$ mm, The Zagreb Archaeological Museum

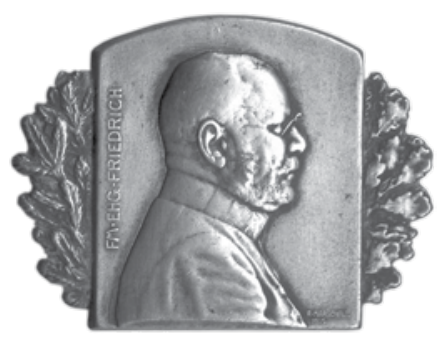

19. Rudolf Marschall, nadvojvoda Friedrich, ratna značka 1915.; željezo, veličina: $43 \times 43 \mathrm{~mm}$, Arheološki muzej u Zagrebu / Rudolf Marschall, Archduke Friedrich, war badge, 1915, iron, dim.: 43 $\times 43 \mathrm{~mm}$, The Zagreb Archaeological Museum

kraljevskim komornim medaljerom, ${ }^{35}$ titulom koja je na habsburškom dvoru postojala već u 16. stoljeću. Dana 8. studenoga 1908. car je svoga medaljera odlikovao vrlo prestižnim Redom željezne krune 3. reda. ${ }^{36}$ Obično se tim odlikovanjem moglo dobiti plemstvo, nešto što R. Marschall nije zatražio. I budući car, prijestolonasljednik nadvojvoda Karlo i njegova žena, nadvojvotkinja Zita, rođ. princeza od Burbon-Parme, imenovali su umjetnika svojim komornim medaljerom 1914. ${ }^{37}$ jer je izradio vrlo lijepu medalju iskovanu u povodu njihova vjenčanja 1911. godine. ${ }^{38}$ Postoje i medalja i plaketa s portretom nesretnoga nadvojvode Franje Ferdinanda. ${ }^{39}$ Njemački car Wilhelm II. odlikovao je Marschalla 1914. Redom pruske krune 3. reda, ${ }^{40}$ jer je i njega portretirao na medalji prethodne godine. ${ }^{41}$ Tijekom Prvoga svjetskog rata umjetnik je dobio i Ratni križ za civilne službenike 2. reda $1918 .{ }^{42}$

Da se vratimo na sam početak. Ime R. Marschalla je naime na jedan neobičan i neočekivan način doprlo do $u$ samu carsku palaču, Hofburg. Bio je još vrlo mlad umjetnik kad su jedan njegov rani rad, neku plaketu, donijeli u ured vrhovnoga carskog dvorskog komornika. Jedan od tamošnjih činovnika oduševio se tom plaketom te ju je pokazivao svojim kolegama, a da nije ni znao umjetnikovo ime. Odgovor je bio neki Marschall. Tako su ta gospoda odlučila plaketu pokazati carevu komorniku. Budući da se i njemu svidjela, odnio ju je caru, pa je i Franjo Josip zaželio 


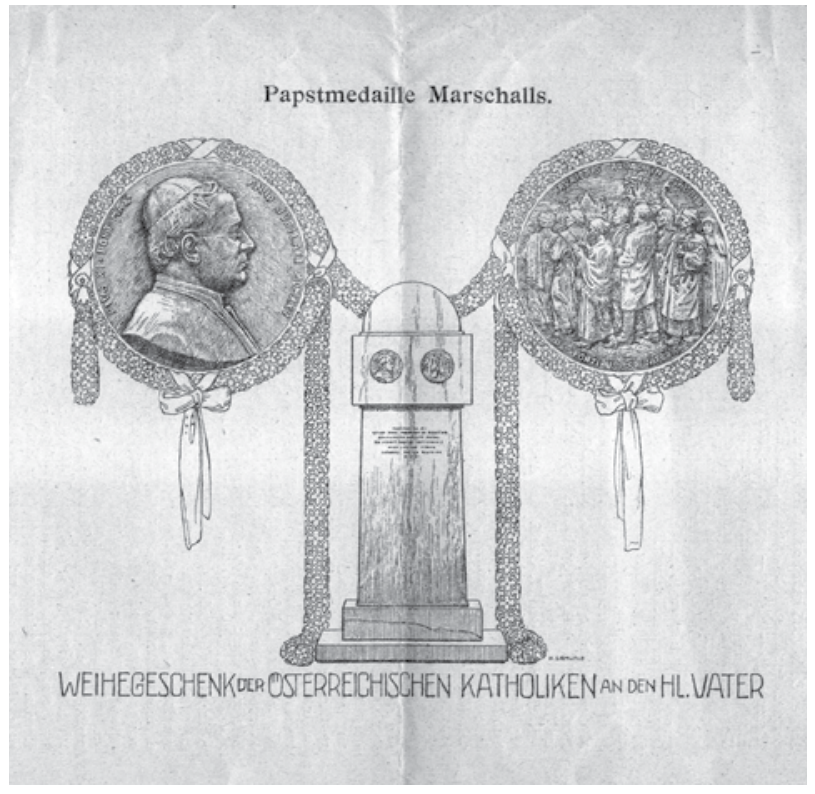

20. Rudolf Marschall, Pio XI., dar austrijskih katolika, 1925. / Rudolf Marschall, Pius XI, gift of the Austrian Catholics, 1925

saznati tko je taj daroviti umjetnik. Tako je Marschallova karijera strelovito i glatko krenula prema zenitu. Sa 25 godina kipar je zamoljen da u povodu careva polustoljetna jubileja vladanja 1898. načini portret: »Medalja sa carevim portretom. Dnevne novine govore nam da je prije nekoliko dana našemu članu gospodinu Rudolfu Marschallu ukazana velika čast da ga u Stjepanovim odajama Carske palače primi Njegovo Veličanstvo zbog poziranja za portret $« .{ }^{43} \mathrm{Na}$ sličan način dvije je godine kasnije, 1900., R. Marschall portretirao cara u povodu njegova sedamdesetog rođendana. ${ }^{44}$ Jedan primjerak te plakete, odliven u zlatu i cizeliran, postavljen na postolje od bijeloga carrarskog mramora, poklonjen je Muzeju dinastije Hohenzollern u Berlinu, ${ }^{45}$ a jedan takav primjerak u lijevanoj bronci postoji i u Numizmatičkoj zbirci Arheološkog muzeja u Zagrebu, kamo je pristigao kao poklon ministra grofa Csákyja 1901. (sl. 8).

Kad se slavio carev šezdeseti jubilej nastupa na prijestolje, i taj je događaj ovjekovječen Marschallovom plaketom. Postoji u dvije veličine $(290 \times 360 \mathrm{~mm}, 150 \times 220 \mathrm{~mm})$ i $\mathrm{u}$ dvije kovine (srebro i lijevana bronca), ali i u kovanim primjercima u srebru i bronci $(63 \times 92 \mathrm{~mm})$, koje se lako moglo kupiti kod renomiranih bečkih tvrtki, kao npr. Braća Egger. Cijene tih komada kretale su se od 18 do 130 kruna. ${ }^{46}$ Za isti jubilej R. Marschall je modelirao i zlatnu nominalu od 100 kruna, smatranu jednim od najljepših kovova toga novijeg doba. ${ }^{47}$ Nadalje je R. Marschall primio narudžbu od zajedničke vojske Austro-Ugarske Monarhije za jednu vrstu križa u kombinaciji zlata i platine, s crvenim emajlom i posutog briljantima, koji je uručen caru Franji Josipu I. dana 2. prosinca $1908 .{ }^{48}$ Budući da je car odbio sve veće proslave

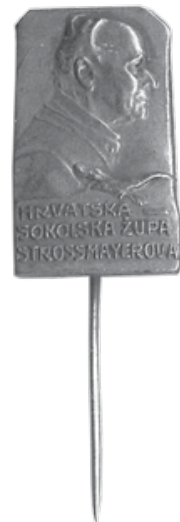

21. Rudolf Marschall, Josip Juraj Strossmayer, Hrvatska sokolska župa Strossmayerova, prije 1929.; značka, bronca, veličina: $17 \times$ 28 mm, Arheološki muzej u Zagrebu / Rudolf Marschall, Josip Juraj Strossmayer, The Croatian Strossmayer Sokol Sports Society, before 1929, badge, bronze, dim.: $17 \times 28$ mm, The Zagreb Archaeological Museum

toga značajnog jubileja, samo je za prigodu vojnog gađanja u Brucku na Leithi R. Marschall izveo plaketu $(45 \times 70 \mathrm{~mm}$; sl. $15){ }^{49}$ kao i vrlo skladan spomen-križ u pozlaćenoj bronci (sl. 16). Taj je križ bio namijenjen vojničkom staležu te dvorskim i civilnim službenicima.$^{50}$ Portret cara Franje Josipa I. od istog majstora vidimo i na nagradnoj medalji Međunarodne lovačke izložbe održane u Beču 1910. godine. ${ }^{51}$ Bečko numizmatičko društvo posvetilo je zasebno izdanje svoga časopisa svim tim izdanjima medalja i plaketa, nastalim u povodu careva šezdesetogodišnjeg jubileja vladanja, pa se tu mogu proučiti sva Marschallova djela.

Uslijedila je i careva narudžba po kojoj je R. Marschall modelirao medalje u povodu zlatnog pira careva rođaka, nadvojvode Rainera, ${ }^{52}$ kao i njegova osamdesetog rođendana. ${ }^{53}$ Ovoj galeriji okrunjenih glava i istaknutih ličnosti pridružuje se i bugarski car koga je umjetnik portretirao u povodu njegova srebrnog jubileja nastupa na prijestolje. I ta medalja postoji u više veličina, ali se portret vidi i na nekoliko nominala optjecajnog novca. ${ }^{54}$

Grad Beč je R. Marschallu platio dva puta u Rim, s ciljem sačinjenja portreta tada vladajućeg pape Leona XIII., a i još jednom kako bi Papi uručio zlatni primjerak kad je ta medalja bila otkovana. Dana 23. svibnja 1900., nekoliko minuta nakon što je tijekom jednog i pol sata pozirao medaljeru, papa je vlastitim rukopisom napisao tekst za naličje medalje: Reclusit thesauros Ecclesiae/ Anno Sancto/ Leo p.p. XIII. Ubrzo je objelodanjen i Marschallov opis devedesetogodišnjeg pape, u kojem kaže da je vrijeme prošlo mimo Svetoga Oca, ostavivši ga neokrnjena zdravlja i živa duha. ${ }^{55} \mathrm{R}$. Marschall nastavio je pravljenje medalja i za pape koji su slijedili: Pija X., ${ }^{56}$ Benedikta XV., Pija XI., Pija XII. te Ivana XXIII., što je jedinstven slučaj u povijesti medaljerstva. I na medalji pape Pija X. iz 1907. na naličju se čita papin rukopis. Portretna 
medalja Pija XI. iz 1925., otkovana za jubilarne godine, bila je poklon austrijskih katolika i postavljena na mramorni blok ispisan prigodnim riječima te podsjeća na spomenik s Dobrim Pastirom, dar papi Leonu XIII. ${ }^{57}$ Medalja pape Pija XII. kovana je 1955. i promjer joj je $90 \mathrm{~mm}$. Na licu vidimo ljude kako se bore, a iznad njih na nebu je Isus Krist, s riječima: DIMITTITE ET DIMITTEMINI (Opraštajte i oprostit će vam se (Lk 6,37)), a na naličju je legenda: PACE NIHIL PERDITUM BELLO OMNIA IN DISCRIMINE POSITA. Prije toga je isto lice medalje upotrijebljeno za pontifikata pape Pija XI., s nešto podužim natpisom na naličju.

Sve je to bilo jako lijepo i dobro, čak prelijepo. No u Beču nitko nije smio uživati u lovorikama u blaženome miru, jer su se božice jala i ogovaranja uvijek skrivale u zasjedi iza svakog ugla. Čak je i prelijepa i inteligentna carica Elizabeta, ona čudna žena (die seltsame Frau), od samih početaka bila glavnom temom ogovaranja i ocrnjivanja, pa je iz godine u godinu sve dulje izbivala iz prijestolnice - tek kad ju je umorio anarhist Luigi Luccheni, općenarodna tuga postala je iskrenom i intenzivnom. Tako se dogodilo da je i R. Marschall, preko volje, uvelike hvaljen, ali je njegov trijumf bio kratkotrajan. Onda je 1905. iznenada eksplodirala već gore spomenuta Affaire Marschall. ${ }^{58}$ Slijed događaja toga skandala u potankosti je u svojoj knjižici koja je doživjela dva izdanja, opisao barun Eugen d’Albon (1859.-1915.; sahranjen je na Bečkom središnjem groblju 8. ožujka), ${ }^{59}$ muž vrlo blizak dvoru i pisac biografija cara Franje Josipa I., carice Elizabete, buduće carice Zite, carevića nadvojvode Rudolfa, njegove najmlađe sestre nadvojvotkinje Marije Valerije i drugih.

Mora da je to bio najveći skandal u povijesti umjetnosti medalje do danas. Nešto je o tome pisao i Ivo Kerdić kojeg smo već citirali. Kao što se već kazalo, R. Marschalla se toleriralo, divili su mu se i priznavali ga na silu, ali protiv volje mnogih uglednika. Bečani su mu čak mogli oprostiti što je, takoreći preko noći, postao auličkim medaljerom cara. No, kad je stari profesor Joseph Tautenhayn pošao u mirovinu, uvijek vrlo oprezni car, vrlo polagan u donošenju odluka, imenovao je R. Marschalla njegovim nasljednikom. Tada je nastala prava buna, s posljedicom neviđenoga štrajka na Umjetničkoj akademiji. Sve su novine bile prepune ozloglašavanja i otrova. $U$ danome trenu imenovana je profesorska komisija čiji je zadatak bio da, kao inkvizicija ili policija, istraži šest točaka »nedjela« s optužnice, koje je navodno skrivio Marschall. U konačnici, kako nam d'Albon piše, nijedna točka »optužnice« nije imala osnova. Usprkos nepopustljivoj podršci Dvora, umjetnik je u izvjesnoj mjeri postao ogorčen čovjek. Austrijsko društvo za numizmatiku i medalje (Österreichische Gesellschaft für Münz- und Medaillenkunde), ${ }^{60}$ kojega je Marschall bio članom od 1898., ${ }^{61}$ također je stalo na umjetnikovu stranu. U godinama koje su slijedile, R. Marschall je često znao uzeti učešća u najrazličitijim polemikama i reagirati po raznim numizmatičkim časopisima, zahtijevajući javne isprike za netočno iznesene podatke o njemu. Obično ga je zastupao odvjetnik dr. Ernst Kuhner. ${ }^{62}$

Kako to opisuje i I. Kerdić, budući da se carski dekret nije mogao poništiti, austrijski ministar za bogoštovlje i nastavu mudro je riješio neugodnu situaciju te 1905 . osnovao novu školu za gravere i medaljere ${ }^{63} \mathrm{i}$ imenovao R. Marschalla - koji je poslije stekao, danas u Republici Austriji još postojeći, naslov dvorskog savjetnika - direktorom. Taj je položaj držao sve do nacističkog Anschlussa 1938. kad je naprasno umirovljen, a škola zatvorena. ${ }^{64}$ Tijekom tisućgodišnje nacističke ere od 1938. do 1945. umjetnik je živio vrlo povučeno. Onda je 5. rujna 1950. reaktiviran te konačno nakon četrdeset godina rada umirovljen ${ }^{65}$ a na ravnateljskom mjestu naslijedio ga je Edwin Grienauer. ${ }^{66}$ Marschallov 80. rođendan dostojno je proslavljen, ${ }^{67}$ pa je tom prigodom odlikovan Počasnom medaljom grada Beča, a i godinu dana kasnije, početkom studenoga, pedeseta obljetnica njegova imenovanja profesorom umjetnosti medalje također je svečano obilježena. ${ }^{68} \mathrm{R}$. Marschall preminuo je u Beču 24. srpnja 1967. i pokopan je na Bečkom središnjem groblju (Gruppe 28, Reihe 27, Grab Nr. 79). ${ }^{69}$

Uz to što je napravio bezbroj medalja i plaketa, R. Marschall se upuštao i u umjetnički obrt te oblikovao brojnu sitnu skulpturu, vaze i svjetiljke, sve u secesijskom stilu, a dio tih predmeta izrađivao se u glasovitoj Wiener Werkstätte. Kad je buknuo Veliki rat 1914. godine, neki radovi R. Marschalla postali su ne samo još popularnijima nego su postizali goleme edicije, kao npr. značke s likovima careva i drugih vojskovođa. ${ }^{70}$ Posebno su bile tražene staklene i kovinske čaše s ukrasnim obručem, na kojima su se mogli vidjeti portreti careva Franje Josipa I. i Wilhelma II., a koje su se prodavale u dobrotvorne svrhe. ${ }^{71}$

R. Marschall se znao susretati s pitanjima u svezi s kršenjem njegovih autorskih prava, pa je jednom objavio tekst o tom problemu uopće. ${ }^{72}$ Prije toga je, npr., na kolajni iskovanoj u povodu zlatnog svećeničkog jubileja pape Pija X. bio prisiljen na rub staviti natpis: GES.GESCH/ COPYRIGHT/ 1908 BY R. MARSCHALL/ DEPOSÉ/ REGD. NR. 518934. ${ }^{73}$ Tijekom Velikoga rata, austrijska kovničarska tvrtka Braća Schneider počela je kovati medalje s portretima austrijskog i njemačkog cara u vojne svrhe. Zadali su nekom kiparu imenom Hans Csadek da kombinira Marschallove portrete obojice careva te je ta medalja iskovana u velikoj nakladi. ${ }^{74}$ Stoga je R. Marschall tužio i tvrtku Schneider i H. Csadeka sudu. Taj se spor završio dana 16. travnja 1915. tako da je spomenuta tvrtka izdala saopćenje glede autorskih prava te se ispričala i povukla sve još postojeće primjerke medalje $s$ tržišta, a R. Marschall je povukao tužbu. ${ }^{75}$

Majstor i njegov car ostali su vjerni jedan drugome sve do careve smrti. R. Marschallu bilo je povjereno uzimanje careve posmrtne maske u noći sa 23. na 24. studenoga 1916. Postoji i priča da je tom prigodom stradao dio legendarne 
"carske« brade Franje Josipa, pa ga se nije moglo izložiti u otvorenomu sarkofagu na katafalku u kapeli Hofburga. Ta posmrtna maska nikad nije predana dvoru, jer se čekalo dostojno i prikladno mjesto za njezin smještaj. A onda odjednom Monarhija više nije postojala. Marschall ju je pokušavao prodati raznim austrijskim i ugarskim političarima. $\mathrm{Na}$ kraju je mađarski premijer grof István Bethlen smogao odgovarajuću svotu novca te je na desetu obljetnicu careve smrti mađarski ministar nastave grof Kuno von Klebelsberg posmrtnu masku izložio u Mađarskom nacionalnom muzeju u Budimpešti. ${ }^{76}$ Nakon propasti Carstva, R. Marschallu je jedino preostala Katolička crkva kojoj je i dalje ostao vjeran, no i Crkva je i njemu ostala vjerna sve do njegove smrti.

U povijesti hrvatskog medaljerstva R. Marschall je i kao autor nekoliko poznatih plaketa odigrao dosta zanimljivu ulogu. Jedna od njih imala je biti otkovana u povodu puštanja u promet uskotračne bosansko-dubrovačke željeznice 1901. godine. Povezivala je Bosnu s dubrovačkom obalom, a tekla je od Sarajeva, preko Mostara, Metkovića, Gruža u Dubrovniku, do Zelenike u Kotorskome zaljevu (sl. 10-11). ${ }^{77}$ Ta plaketa sačuvana je u više kovina (zlato, srebro, bronca), a postoje i jednostrani primjerci. Na licu vidimo muškar$\mathrm{ca}$, odjevena u hercegovačku narodnu nošnju, zajedno s natovarenom mulom, kako $s$ krških brda silazi prema luci, sličnoj Gružu. Na naličju pak možemo vidjeti kompoziciju vlaka s lokomotivom, kako prelazi preko vijadukta, prije no što uđe u tunel. Naum medaljera bio je pokazati razliku između načina transporta robe iz zaleđa prema Jadranu u prošlosti i promjenu nakon probijanja željezničke pruge. Nažalost, i ta plaketa nije prošla bez neugodnih konotacija: kad su je pokazali austro-ugarskome ministru financija koji je upravljao Bosnom i Hercegovinom, Benjaminu Kallayu de Nagy-Kalló, nije mu se otprve uopće svidjela te je najodlučnije pokušavao da se zabrani njezino raspačavanje. Glavni argument bio je da magarac ne smije biti glavnim motivom na jednoj plaketi! Čak je dao avers svojega srebrnog primjerka odbrusiti. Austro-ugarsko ministarstvo bilo je u nedoumici, pa je dalo pitati nekog profesora Dalmatinca bili i ljudi u Dalmaciji također bili povrijeđeni iz istoga razloga, a on je dao pozitivan odgovor. Stoga je veći dio edicije tih plaketa uništen, no srećom je manji dio sačuvan, ${ }^{78}$ počam od zlatnog otkova u Bečkom numizmatičkom kabinetu. ${ }^{79}$ Tako veći dio tih plaketa nema nikakva lica. ${ }^{80}$

Druga plaketa, sačinjena 1905., trebala je obilježiti 90. rođendan glasovitog biskupa Josipa Jurja Strossmayera kojega je Marschall portretirao još za života. No, biskup je preminuo i plaketa je otkovana u povodu njegove smrti. Stoga je R. Marschall na naličje plakete postavio nagoga muškog genija kako sjedi zdesna na oblacima, podiže desnicu, a iz ljevice pušta pasti zublju (sl. 12-13). ${ }^{81}$ Prije 1929. Marschallov avers te plakete reduciran je za značku Hrvatske sokolske Strossmayerove župe (sl. 21). ${ }^{82}$
Dodatni razlog zašto je R. Marschall važan u povijesti hrvatskog medaljerstva jest činjenica da je bio učiteljem Ive Kerdića. I stoga smo u ovome članku citirali neke izvatke iz Kerdićevih memoara.

\section{BILJEŠKE}

1 Usp. IVAN MIRNIK, Radovi Valdeca, Frangeš-Mihanovića i Kerdića u Numizmatičkoj zbirci Arheološkog muzeja u Zagrebu, Peristil, 32 (1988.1989.), 31-32; 267-275; IVAN MIRNIK, Ivo Kerdić, The Medal, 16 (1990.), 53-57; IVAN MIRNIK, Ivo Kerdić (1881-1952). Medalje i plakete iz fundusa Arheološkog muzeja u Zagrebu, Zagreb, 2004.; IVAN MIRNIK, Ivo Kerdić: umjetnik i njegov model, Peristil, 51 (2008.), 71-88; IVAN MIRNIK, The artist and the model. Ivo Kerdić, William Chauncy Langdon and others, The Medal, 59 (2011.), 28-46; IVAN MIRNIK, Hrvatsko-američki doticaji na području medaljerstva: Ivo Kerdić $i$ William Chauncy Langdon, I. dio, Numizmatičke vijesti, 55/66 (2013.), 189-207.

2 Hans Bitterlich (Beč, 28. IV. 1860. - 5. VIII. 1949.), austrijski kipar.

3 K. k. Graveur- und Medailleurschule in Wien. Usp.: Mitteilungen der Österreichischen Gesellschaft für Münz- und Medaillenkunde, 2, Wien, 1906., br. 8 (195), 74, 75.

4 Josef Václav Myslbek (Prag, 20. VI. 1848. - 2. VI. 1922.), češki kipar i medaljer.

5 IVO KERDIĆ, Moj život i uspomene, rukopis, 45-47.

6 Mitteilungen der Österreichischen Gesellschaft für Münz- und Medaillenkunde, 6, Wien, 1910., br. 6 (241), 86.

7 U vrijeme kad je I. Kerdić diktirao svoje memoare, R. Marschall bio je živ, a ionako je nadživio Kerdića.

8 Mitteilungen der Österreichischen Gesellschaft für Münz- und Medaillenkunde, 2, Wien, 1906., br. 8 (195), 74, 75.

9 Najsrdačnija hvala kolegi Tomàšu Kleisneru, voditelju Numizmatičkog kabineta češkoga Narodnog muzeja u Pragu na podacima. Usp. Mitteilungen der Österreichischen Gesellschaft für Münz- und Medaillenkunde, 2, Wien, 1906., br. 8 (195), 75.

10 Usp. IVAN MIRNIK, Robert Frangeš-Mihanović, The Medal, 14 (1989.), 60-62.

11 IVO KERDIĆ, Moj život i uspomene, rukopis, 63-64.

12 Usp. ULRICH THIEME, FELIX BECKER, Allgemeines Lexikon der bildenden Künstler, vol. 24, Leipzig, 1930., 139; AUGUST LOEHR, Die Medaille in Österreich, Numismatische Zeitschrift, 73 (1949.), 140; EMMANUEL BÉNÉZIT, Dictionnaire critique et documentaire des peintres, sculpteurs, dessinateurs et graveurs, sv. V, Paris, 1966., 798; BERNHARD KOCH, 100 Jahre Österreichische numismatische Gesellschaft 1870-1970. Festschrift, Wien, 1970., 13, 40, 100, 103, 106, 109-110, 112, 117, 131, 134, 136, 141142, 148, 155; KARL SCHULZ, Die Medaille in Österreich, Numismatische Zeitschrift, 100 (1989.), 199-201; GEORG MACK, Leben und Werk des Medailleurs Rudolf Marschall (1873-1967). Diplomarbeit zur Erlangung des Magistersgrades an den Geisteswissenschaftlichen Fakultät der LeopoldFranzens-Universität Inssbruck, Innsbruck, 1992. (Najsrdačnije zahvaljujem kolegi dr. Hubertu Emmerigu s bečkoga Numizmatičkog instituta za ovaj podatak.); WALTHER KILLY, RUDOLF VIERHAUS (ur.), Deutsche biographische Encyklopädie, sv. 6, München, 1999., 631.

13 Mitteilungen der Österreichischen Numismatischen Gesellschaft, 6 (22), Wien, 1949., br. 2, 24.

14 AUGUST RITTER VON LOEHR, Wiener Medailleure 1899, Wien, 1899., 40, 42, T. 25, B6, B11.

15 Medailleur Rudolf Marschall, unserem geehrten Mitgliede, wurde für seine auf der XXIX. Ausstellung der Künstlergenossenschaft ausgestellten Medaillen die goldene Staatsmedaille verliehen. Die Schriftleitung. U: Monatsblatt der numismatischen Gesellschaft in Wien, 5, Wien, 1902., br. 225 (28), 303.

16 AUGUST RITTER VON LOEHR (bilj. 14), 12. 
17 AUGUST RITTER VON LOEHR, Wiener Medailleure. Nachtrag 1901, Wien, 1902.

18 AUGUST RITTER VON LOEHR (bilj. 17), 54-55, T. 29-33. 19 LEONARD FORRER, Biographical Dictionary of Medallists Medallists coin-, gem-. and seal-engravers mint-masters, \& c. ancient and modern with references to their works B.C. 500 - A.D. 1900 compiled by..., vol. III, London, 1907., 580-586.

20 Usp.: Mitteilungen der Österreichischen Gesellschaft für Münz- und Medaillenkunde, 1, Wien, 1905., br. 9-10 (184-185), 91-92; 2, Wien, 1906., br. 2 (189), 13, 21, 37; br. 8 (195), 78-79; br. 12 (199), 6; 3, Wien, 1907., br. 1 (200), 7; 4, Wien, 1908., br. 6 (217), 69-70; br. 11 (222), 127, 129; br. 12 (223), 146, 148, 150, T. 3, 1-2; T. 4; 5, Wien, 1909., br. 2 (225), 20, 21-22; br. 4 (227), 49, 50-51, T. 2-6; 53, 55; br. 5 (228), 67, 68, 71, 72; br. 6 (229), 85, 86, 87; 7 (230), 89, 94, 97-98; br. 8 (231), 101-105; br. 9 (232), 113-116; br. 10 (233), 129-132; br. 12 (235), 179; 6, Wien, 1910., br. 7 (242), 102; 7, Wien, 1911., br. 2 (249), 30; br. 3 (250), 50; br. 5 (252), 84, 87; br. 7 (254), 110; 8, Wien, 1912., br. 3 (262), 50-51, 57; br. 11 (279), 239, T. 15 , br. $148 ; 9,1913$., br. 2 (273), 37; br. 7 (278), 121, 133-135; br. 10 (281), 157; br. 11 (282), 171; 13, Wien, 1917., br. 9 (329), 101; Monatsblatt der numismatischen Gesellschaft in Wien, 5, Wien, 1901.-1902., 10, 55, 75, 79, 198, 199, 214, 261, 268, 276, 317; 6, Wien, 1903.-1905., 10, 26, 41, 185, 253, 265, 234, 280, 281, 371; 7, Wien, 1906.-1908., 13, 72, 100, 110, 141, 157, 300, 373, 400, 401; 8, Wien, 1910., 17, 28, 84, 101, 111, $121,122,133,164,165,218,230,248,308,360$; 8, Wien, 1910., 236 (13), 133; 9, Wien, 1912.-1914., 50, 124, 164, 177, 240, 250, 262; 10, Wien, 1915.-1916., 9, 38, 46, 59, 81, 191; Mitteilungen der numismatischen Gesellschaft in Wien, 15, Wien, 1924., br. 61-62, 243; 16, Wien, 1926. br. 83-85, 316-317; Mitteilungen der Österreichischen Numismatischen Gesellschaft, 9 (25), Wien, 1956., br. 10, 82.

21 Revue de l'Art, 2, Paris, 1900., 40; usp. LEONARD FORRER (bilj. 19), 584 .

22 Numismatic Circular, 1901., col. 4893; usp. LEONARD FORRER (bilj. 19), 585-586.

23 Mitteilungen der Österreichischen Gesellschaft für Münz- und Medaillenkunde, 2, Wien, 1906., br. 11 (198), 121-122.

24 Kaiserjubiläums-Ausstellung der Österr. Gesellschaft für Münz- und Medaillenkunde in Wien održavala se u Künstlerhausu od 26. studenoga do 27. prosinca 1908.

25 Mitteilungen der Numismatischen Gesellschaft in Wien, 4 (20), Wien, 1946., br. 8, 76 .

26 EDUARD HOLZMAIR, Kammermedailleur Hofrat Prof. Rudolf Marschall 80 Jahre alt, Mitteilungen der Österreichischen Numismatischen Gesellschaft, 8 (24), Wien, 1953., br. 6, 41.

27 KARL SCHULZ (bilj. 12), 201.

28 BERNHARD KOCH (bilj. 12), 134, 148, T. 9, 11.

29 Zanimljivo je što je i E. Dollfussa i njegovu majku portretirao Zagrepčanin Oskar Artur Alexander.

30 Plaketa (bronca, $82 \times 99 \mathrm{~mm}$ ) nastala je 1949. Usp.: Mitteilungen der Österreichischen Numismatischen Gesellschaft, 8 (24), Wien, 1954. br. 9,69 .

31 Monatsblatt der numismatischen Gesellschaft in Wien, 6, Wien, 1903., br. 257 (24), 281

32 Monatsblatt der numismatischen Gesellschaft in Wien, 6, Wien, 1903., br. 234 (1), 10.

33 Monatsblatt der numismatischen Gesellschaft in Wien, 8, Wien, 1910., br. 318 (13), 133.

34 Mitteilungen der Österreichischen Gesellschaft für Münz- und Medaillenkunde, 5, Wien, 1909., br. 10 (233), 179.

35 Monatsblatt der numismatischen Gesellschaft in Wien, 6, Wien, 1903. br. 236 (3), 41.

36 Mitteilungen der Österreichischen Gesellschaft für Münz- und Medaillenkunde, 3, Wien, 1907., br. 12 (223), 152; Monatsblatt der numismatischen Gesellschaft in Wien, 7, Wien, 1908., br. 305 (36), 404.

37 Monatsblatt der numismatischen Gesellschaft in Wien, 9, Wien, 1914. br. 374 (33), 250.
38 Monatsblatt der numismatischen Gesellschaft in Wien, 9, Wien, 1913., br. $362(21), 164, \mathrm{~T} 14$.

39 Monatsblatt der numismatischen Gesellschaft in Wien, 9, Wien, 1914., br. 373 (32), 240, T. 15, 19.

40 Monatsblatt der numismatischen Gesellschaft in Wien, 6, Wien, 1904., br. 247 (14), 185.

41 Monatsblatt der numismatischen Gesellschaft in Wien, 9, Wien, 1913., br. $362(21), 164$.

42 Monatsblatt der numismatischen Gesellschaft in Wien, 11, Wien, 1918., br. 419 (6), 42.

43 Porträt-Medaille des Kaisers. Die Tages-Journale melden, dass vor einigen Tagen unserem Mitgliede acad. Bildhauer und Medailleur Herrn Rudolf Marschall die hohe Ehre zutheil wurde, von Sr. Majestät zu einer Porträtsitzung in den Stephansappartements der Hofburg empfangen zu werden. Die Schriftleitung. U: Monatsblatt der numismatischen Gesellschaft in Wien, 5, Wien, 1900., br. 199 (2), 37.

44 Numismatische Zeitschrift, 33, Wien, 1902., omot.

45 Monatsblatt der numismatischen Gesellschaft in Wien, 6, Wien, 1903., br. 266 (33), 371.

46 Monatsblatt der numismatischen Gesellschaft in Wien, 7, Wien, 1908., br. 296 (27), 300; ALOIS RICHTER, Die numismatischen Denkzeichen auf die Regierungsjubiläen des Kaisers Franz Josef I. (1853-1908), Zeitschrift für Münz- und Medaillenkunde, 2, Wien, 1908.-1913., br. 3, 253, br. 291 -292 ; T. 22 ,

47 Monatsblatt der numismatischen Gesellschaft in Wien, 7, Wien, 1908., br. 303 (34), 373, 401, T. 5 .

48 Monatsblatt der numismatischen Gesellschaft in Wien, 7, Wien, 1908., br. 305 (36), 397-398, T. 2.

49 Monatsblatt der numismatischen Gesellschaft in Wien, 7, Wien, 1908., br. 305 (36), 400, T. 3.

50 Monatsblatt der numismatischen Gesellschaft in Wien, 7, Wien, 1908., br. 305 (36), 401, T. 4.

51 Monatsblatt der numismatischen Gesellschaft in Wien, 9, Wien, 1913., br. 357 (16), 124-125.

52 Monatsblatt der numismatischen Gesellschaft in Wien, 5, Wien, 1902., br. 224 (27), 276-277.

53 Mitteilungen der Österreichischen Gesellschaft für Münz- und Medaillenkunde, 3, Wien, 1907., br. 1 (200), 7; Monatsblatt der numismatischen Gesellschaft in Wien, 8, Wien, 1909., br. 308 (3), 28.

54 Mitteilungen der Österreichischen Gesellschaft für Münz- und Medaillenkunde, 8, Wien, 1912., br. 11 (279), 239; 9, Wien, 1913., br. 2 (273), 37; Monatsblatt der numismatischen Gesellschaft in Wien, 9, Wien, 1912., br. 348 (7), 50.

55 A. FRIEDRICH, Medaille Papst Leo XIII, Monatsblatt der numismatischen Gesellschaft in Wien, 5, Wien, 1902., 199; LEONARD FORRER (bilj. 19), 385; KARL SCHULZ (bilj. 12), 200; GIANCARLO ALTERI, La medaglia pontificia da Leone XIII a Giovanni Paolo II, Udine, 1992., 75. 56 IVAN MIRNIK, Numizmatička zbirka Arheološkoga muzeja u Zagrebu. Donacije 1990.-2010. / The Numismatic Collection of the Zagreb Archaeological Museum. Donations 1990-2010, Zagreb, 2010., 133, br. 489.

57 Mitteilungen der numismatischen Gesellschaft in Wien, 15, Wien, 1926., br. 83-85, 311, 316-317.

58 EUGEN BARON D’ALBON, Die Affaire Marschall, Wien, 1905.; HELMUT JUNGWIRTH, Die Meisterschule für Medaillenkunst an der Akademie für bildende Künste in Wien, Numismatische Zeitschrift, 99, Wien, 1985., 78-79; KARL SCHULZ (bilj. 12), 200.

59 WILHELM KOSCH, Deutsches Literatur-Lexikon. Das 20 Jahrhundert, sv. I. Aab-Bauer, Bern-München, 2000, 125.

60 Bečka numizmatička društva su tijekom povijesti više put mijenjala imena, pogotovo tijekom 20. stoljeća.

61 Adresa škole bila je Wien IV, Graf Starhembergerstrasse 25, telefonski broj U-40-204, a njegova stambena adresa bijaše isprva Mariahilferstrasse 89 a, potom Graben 3, Payerbach, Austrija. U poznijim godinama stanovao je u Hansnerstrasse kbr. 20, Wien XVI, usp. Mitglieder der Österreichischen Numismatischen Gesellschaft, Numismatische Zeitschrift, 32, Wien, 1900., 
305; 33, Wien, 1901., 299; 34, Wien, 1903., 345; 35, Wien, 1903., 371; 36, 1904., 237; 37, Wien, 1906., 245; 38, Wien, 1906., 285; 1 (41), Wien, 1908., 321; 2 (42), Wien, 1909., 301; 3 (43), Wien, 1910., 309; 4 (44), Wien, 1911., 257; 5 (45), Wien, 1913., 231; 6 (46), Wien, 1914., 255; 7 (47), Wien, $1915 .$, 250; 9 (49), Wien, 1917., 219; 10 (50), Wien, 1917., 224; 11 (51), Wien, 1918., 241; 13 (53), Wien 1920., 2; 17 (57), Wien, 1924., 149; 19 (59), Wien 1926., 185; N. F., 20 (60), Wien, 1927., 135; 77, Wien, 1957., 78. Njegovo ime čitamo i na popisu članova Numizmatičkog društva u Beču za 1940. godinu. Marschallov 70. rođendan spomenut je i u Mitteilungen der $\mathrm{Nu}$ mismatischen Gesellschaft in Wien, 4 (20), Wien, 1943., br. 3, 34. Godine 1949. Austrijsko numizmatičko društvo sjetilo se Marschallova polustoljetnog članstva: Mitteilungen der Österreichischen Numismatischen Gesellschaft, 6 (22), Wien, 1949., br. 4, 47; br. 11, 127-128.

62 Primjerice: Kammermedailleur Prof. Rudolf Marschall. An die Herren Mitglieder der Österreichischen Gesellschaft für Münz- und Medaillenkunde und die Herren Abonnenten, der Mitteilungen der Gesellschaft, od 20. prosinca, 1913. Prilog: Mitteilungen der Österreichischen Gesellschaft für Münz- und Medaillenkunde, 9, Wien, 1912., br. 12 (283).

63 Graveur- und Medailleurschule; godine 1914. preimenovana je u Akademische Spezialschule für Medaillenkunst, a 1921. u Meisterschule für Medaillenkunst. HELMUT JUNGWIRTH, Die Meisterschule für Medaillenkunst an der Akademie für bildende Künste in Wien, Numismatische Zeitschrift, 99, Wien, 1985., 79.

64 Mitteilungen der Österreichischen Numismatischen Gesellschaft, 6 (22), Wien, 1950., br. 7, 79.

65 Mitteilungen der Österreichischen Numismatischen Gesellschaft, 6 (22), Wien, 1950., br. 12, 145.

66 HELMUT JUNGWIRTH (bilj. 63), 79.

67 EDUARD HOLZMAIR, Kammermedailleur Hofrat Prof. Rudolf Marschall 80 Jahre alt, Mitteilungen der Österreichischen Numismatischen Gesellschaft, 8 (24), Wien, 1953., br. 6, 41.

68 Mitteilungen der Österreichischen Numismatischen Gesellschaft, 8 (24), Wien, 1954., br. 12, 96.

69 BERNHARD KOCH, Biographische Beiträge zur Geschichte der Wiener Münzstempelschneider und Medailleure, Numismatische Zeitschrift, 82, Wien, 1967., 72, T. 9.
70 Mitteilungen der Österreichischen Gesellschaft für Münz- und Medaillenkunde, 13, Wien 1917., br. 9 (329), 101.

71 Monatsblatt der numismatischen Gesellschaft in Wien, 10, Wien, 1915., br. 385 (8), 59; JELENA BOROŠAK MARIJANOVIĆ (ur.), Dadoh zlato za željezo. Prvi svjetski rat u zbirkama Hrvatskog povijesnog muzeja, Zagreb, 2011., 530-531, br. VI/26-27.

72 Monatsblatt der numismatischen Gesellschaft in Wien, 9, Wien, 1913., br. 357 (16), 119-123

73 IVAN MIRNIK (bilj. 56), 133, br. 489.

74 Monatsblatt der numismatischen Gesellschaft in Wien, 10, Wien, 1915., br. 383 (6), 46 .

75 Monatsblatt der numismatischen Gesellschaft in Wien, 10, Wien, 1915. br. 383 (6), 47.

76 ITALO ZINGARELLI, Stara Austrija, Zagreb, [1938?], 145.

77 MILAN REŠETAR, Dubrovačka numizmatika, I., Srijemski Karlovci, 1924., 546-547; MILAN REŠETAR, Dubrovačka numizmatika, II., Beograd-Zemun, 1925., 314, br. 3404-3405; BOŽE MIMICA, Numizmatička povijest Dubrovnika. Historia ragusina in nummis, Rijeka, 1994., 409. 78 MILAN REŠETAR (bilj. 77, 1925.), 314a.

79 MILAN REŠETAR (bilj. 77, 1925.), 314, br. 3404.

80 MILAN REŠETAR (bilj. 77, 1925.), 314, br. 3405.

81 Mitteilungen der Österreichischen Gesellschaft für Münz- und Medaillenkunde, 2, Wien, 1906., br. 11 (198), 121; Monatsblatt der numismatischen Gesellschaft in Wien, 7, Wien, 1907., br. 282 (13), 141; 8, Wien, 1910., br. 320-321 (15-16), 165, T. XIV; NADA TODOROVIĆ, Jugoslovenske i inostrane medalje. Médailles yougoslaves et étrangères, Beograd, 1964., 88-89, br. 191; VINKO ZLAMALIK, Medalja u Hrvatskoj, Zagreb, 1964., 33-34, br. 44-45; HERMINE GÖRICKE-LUKIĆ, Medalje i plakete iz zbirke Muzeja Slavonije Osijek, 15.-20. stoljeće, katalog izložbe, Osijek, 1993., 148-149, br. 344; IVAN MIRNIK, Zbirka medalja Berislava Kopača, Zagreb, 2005., 125, br. 377; TATIJANA GARELJIĆ, Zbirka medalja i plaketa inž. Dragutina Mandla, Zagreb, 2009, 17.

82 IVAN MIRNIK (bilj. 81), 125, br. 378. 
Summary

Ivan Mirnik

Rudolf Marschall and Ivo Kerdić

RudolfFerdinand Marschall (Vienna, 1873 - Vienna, 1967) was one of the most celebrated among the many medallists of the Sezession in Austria. He modelled medals with the portraits of two Austrian emperors, the German Emperor, the Czar of Bulgaria, the popes from Leon XIII to John XXIII, and many more illustrious persons of the first half of the $20^{\text {th }}$ century. In 1905 he was involved into the so-called "Affaire Marschall". Namely, when his teacher Joseph Tautenhayn retired the Emperor appointed R. Marschall as his successsor, the hell broke loose, including an unseen general strike at the Academy of Fine Arts. Since the Emperor's decree could not be annulled, the Austrian minister of Religion and Education founded a new school for engravers and medallists in 1905 and appointed R. Marschall its director, a post he held until the Anschluss in 1938, when he was retired and the school closed. The Marschall Affair was also described by one of the eyewitnesses, Ivo Kerdić, the Croatian pupil of Marschall's in his unpublished memoirs "Moj život i uspomene" (My life and memories). For the history of Croatian medal R. Marschall has some significance, because he was the author of several important plaquettes. One of them was struck on the occasion of the inauguration of the Bosnian-Dubrovnik narrow-track railway in 1901. It connected Bosnia with the coast of Dubrovnik, running from Sarajevo, via Mostar, Metković, Gruž in Dubrovnik, to Zelenika in the Bay of Kotor. The other plaquette was made in 1905, and originally it was planned to mark the $90^{\text {th }}$ birthday of the famous Roman Catholic bishop Josip Juraj Strossmayer, whom R. Marschall had portrayed while still alive. However, the bishop died and the plaquette was issued on the occasion of his demise.

Translation: Ivan Mirnik 